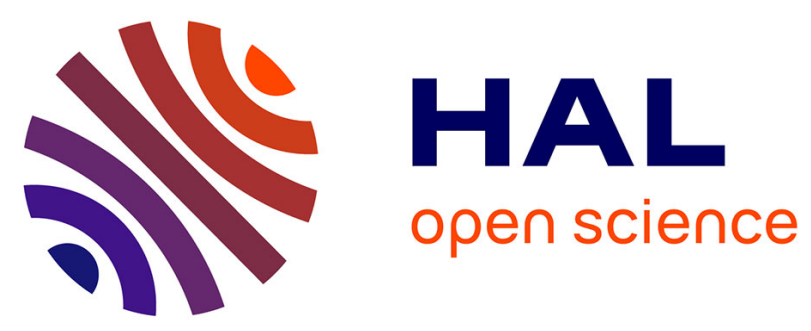

\title{
High pressure cell to measure the depolarization ratio of the light scattered by gases
}

\author{
J. Berrue, A. Chave, B. Dumon, M. Thibeau
}

\section{To cite this version:}

J. Berrue, A. Chave, B. Dumon, M. Thibeau. High pressure cell to measure the depolarization ratio of the light scattered by gases. Revue de Physique Appliquée, 1977, 12 (10), pp.1743-1746. 10.1051/rphysap:0197700120100174300 . jpa-00244396

\section{HAL Id: jpa-00244396 https://hal.science/jpa-00244396}

Submitted on 1 Jan 1977

HAL is a multi-disciplinary open access archive for the deposit and dissemination of scientific research documents, whether they are published or not. The documents may come from teaching and research institutions in France or abroad, or from public or private research centers.
L'archive ouverte pluridisciplinaire HAL, est destinée au dépôt et à la diffusion de documents scientifiques de niveau recherche, publiés ou non, émanant des établissements d'enseignement et de recherche français ou étrangers, des laboratoires publics ou privés. 


\title{
HIGH PRESSURE CELL TO MEASURE THE DEPOLARIZATION RATIO OF THE LIGHT SCATTERED BY GASES
}

\author{
J. BERRUE, A. CHAVE, B. DUMON and M. THIBEAU \\ L.E.I.M.D.L., Faculté des Sciences, 49045 Angers Cedex, France
}

(Reçu le 24 janvier 1977, révisé le 3 mai 1977, accepté le 27 juin 1977)

\begin{abstract}
Résumé. - On présente un appareillage facile à réaliser permettant de mesurer des taux de dépolarisation supérieurs à $10^{-4}$. La principale difficulté rencontrée vient de la biréfringence accidentelle. Nous indiquons comment la minimiser par construction mécanique et comment tenir compte de la biréfringence résiduelle par un calcul et des contrôles appropriés.
\end{abstract}

Abstract. - An easily assembled apparatus permitting the measurement of depolarization ratio higher than $10^{-4}$ is presented. The major difficulty arises from the depolarization, due to the birefringence of the windows under stress. We explain how to minimize it by mechanical means, and how to deal with the problem of residual birefringence by appropriate calculation and tests.

1. Principle. - The apparatus presented permits measurements under pressures up to 500 bar and temperatures between 25 and $200{ }^{\circ} \mathrm{C}$. A linearly polarized beam from an argon ion laser passes through a cell containing the high pressure gas. Then the light, scattered at $90^{\circ}$, is analyzed. The plane of scattering is horizontal. By means of a half-wave plate, the polarization of the incident beam is horizontally (h) or vertically (v) oriented. We measure a polarized intensity $V \mathrm{v}$ and three depolarized intensities $H \mathrm{~h}, H \mathrm{v}, V \mathrm{~h} ; H$ and $V$ indicating the polarization of the scattered beam.

Away from the critical point, the three depolarized intensities are equal and inferior to $V \mathrm{v}$. The depolarization $(\eta)$ is defined by the ratio of one of the depolarized intensities to $V \mathrm{v}$. Three difficulties arose :

a) The birefringence of the stressed windows under pressure;

b) The parasitic light and;

c) The poor geometrical definition of the scattered beam due to the finite apertures of the diaphragms. How these problems can be solved is indicated.

The study of the depolarized intensities in the fluids permits a better knowledge of the interactions, the molecular distributions, the thermodynamic properties of the fluids (see examples [1] to [7]) and of the collision induced anisotropy ([4], [8]).

2. Apparatus. - The cell of KNDMO steel (Fig. 1) is formed of 4 perpendicular branches containing diaphragms which minimize the parasitic light due to the reflection on the edges of the cell, and limit the aperture of beam on the photomultiplier's side.

The windows are cylinders of tempered PUROP-

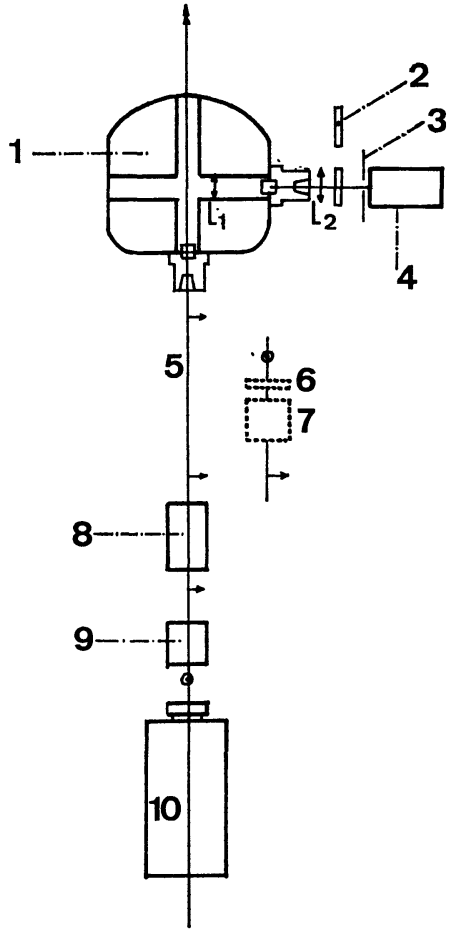

FIG. 1. - (1) high pressure cell, (2) analysing polaroïds, (3) iris diaphragm, (4) photomultiplier, (5) incident beam, (6) density plate, (7) half wave plate, (8) glazebrook, (9) half wave plate, (10) laser.

SIL. A which presents a small birefringence under stress. The residual depolarization, which cannot be minimized easily will depend essentially on the pressure and mechanical bearings (Fig. 2) of the window in its mounting screwed to the cell. The use of steel 


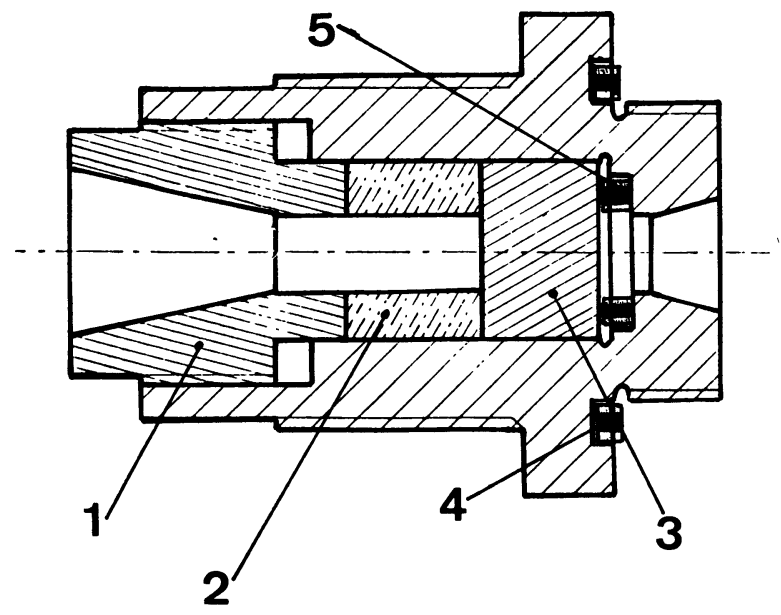

FIG. 2. - (1) hold-down nut, (2) polished cylinder (KNDMOsteel), (3) window (PUROPSIL A), (4) QUINSON ring - DN 20, (5) QUINSON ring - DN 4.

polished cylinders, causes a better distribution of the stress. The gas tightness is achieved by means of QUINSON rings. The apparatus must be carefully assembled and stabilized for full reliability of the measurements. The main difficulty is to obtain a good polarization of the incident beam. The horizontal polarization must be accurately realized; the fine control of the latter is obtained by detecting a minimum fo $V$ h with the P.M. A slight vertical component will entail an important increase of the detected signal. A retractable system supporting a half-wave plate gives the vertical polarization whose adjustment is less critical.

On the scattering side, $H$ h must be separated from $V \mathrm{~h}$, and $V \mathrm{v}$ from $H \mathrm{v}$, according to incident beam polarization. $V \mathrm{v}$ is $10^{3}$ times bigger than the three depolarized components which are all equal. So, it's not necessary to use a high quality polarizing prism, and the use of polaroï, the adjustment of which is not critical in this case, gives the same kind of results as those obtained by a glazebrook for instance. We have chosen the polaroïds because their size allows their setting in revolving systems. The difficulty lies in the reproducible setting of pre-adjusted polaroïs. The pre-adjustement of the horizontal positioning of a most critical setting is made by detecting a minimum of $H \mathrm{v}$ with the P.M. A light-tight revolving mechanism is used.

To make measurements at different temperatures, a heating-plate was placed against the cell; the temperature is stabilized at $1 / 10^{\circ} \mathrm{C}$. It must be heated progressively to avoid extra stress on the windows.

The cell is isolated from its support by quartz-balls. The cooled P.M. being thermically protected by brass-bellows.

3. Experimental difficulties. - The main difficulty is to maintain the polarization of the incident and scattered beams, when they cross the windows of the high pressure cell. Special care must be given to the fitting of the window-holders. Besides, simultaneous measurements of $H \mathrm{~h}, \mathrm{~h}, H \mathrm{v}$ control the depolarization of the stressed windows, by comparing the values of the depolarized components that must be equal, when there is no stress. We have indicated how to take into account those depolarizations when they're small, to obtain the exact value of the depolarization ratio.

$\eta$ is defined as being $H \mathrm{~h} / V \mathrm{v}$ or $V \mathrm{~h} / V \mathrm{v}$ or $H \mathrm{v} / V \mathrm{v}$ when there's no windows' depolarization. Let $\beta$ be the depolarization ratio introduced through the entrance window on the incident beam, $\beta^{\prime}$ the one introduced on the scattering side, $V$ vo the intensity of $V v$ if $\beta$ and $\beta^{\prime}$ were nil; we can establish the following indentities:

$$
\begin{aligned}
& H \mathrm{~h}=\eta+\eta \beta+\eta \beta^{\prime}+\beta \beta^{\prime} \\
& H_{\mathrm{v}}=\eta+\beta^{\prime}+\eta \beta^{\prime}+\eta \beta \beta^{\prime} \\
& V \mathrm{~h}=\eta+\beta+\eta \beta^{\prime}+\eta \beta \beta^{\prime} \\
& V_{\mathrm{v}}=1+\eta \beta+\eta \beta^{\prime}+\eta \beta \beta^{\prime}
\end{aligned}
$$

The intensity unit being: $V \mathrm{vo} /(1+\beta)\left(1+\beta^{\prime}\right)$.

In the range of pressure that were used, the values of $\beta$ and $\beta^{\prime}$ have reached $10^{-3}$. The measurements of $H \mathrm{v} / V \mathrm{v}$ and $V \mathrm{~h} / V \mathrm{v}$ are disturbed, while $H \mathrm{~h} / V \mathrm{v}$ is less affected, as shown in (1). So we decided to devote our study to the ratio $H \mathrm{~h} / V \mathrm{v}$ essentially, taking the effect of window depolarization into account on using the experimental values of $H \mathrm{v} / V \mathrm{v}$ and $V \mathrm{~h} / V \mathrm{v}$.

From (1) a good approximation of $\eta$ is derived which allows the control of the parasitic depolarization.

$$
\eta=\frac{H \mathrm{~h}}{V \mathrm{v}}-\frac{H \mathrm{v} \cdot V \mathrm{~h}-(H \mathrm{~h})^{2}}{(V \mathrm{v})^{2}}
$$

Yet another experimental difficulty is encountered when collecting the scattered light since infinetely small diaphragms cannot be used, and we no longer operate at a rigorous $90^{\circ}$ of the incident beam which confuses the intensities $H \mathrm{~h}, V \mathrm{~h}$ and $V \mathrm{v}$. This confusion adds supplementary constants $\left(\sim 0.5 \times 10^{-3}\right)$ to the ratios $H \mathrm{~h} / V \mathrm{v}$ and $V \mathrm{~h} / V \mathrm{v}$ [5]. Those constants are related to the solid angle of the scattered beam; they don't disturb the study of the variation of versus the density of the gases, but, they must be substracted for absolute measurements.

In theory, the depolarization ratio, that is proportional to the number of atoms, must be null at the origin of the pressures. The constants are obtained by measuring the depolarization ratio of argon under zero pressure, by extrapolating the curves. The optimal inclination of the rays can be obtained by means of lenses $L_{1}$ and $L_{2}$ while sufficient luminosity is maintained. The iris-diaphragm $\mathrm{D}$ is at the focus of the system $L_{1}$ and $L_{2}$; the inclination of the scattered rays detected by the P.M. can be diminished by closing the iris-diaphragm. The bearing of the window which is at the $L_{1}$ focus plays the role of a dia- 
phragm. So, all the selected rays may come from the whole surface of $\mathrm{L}_{1}$.

The parasitic light disturbs the measurement of $H$ h too: it is mainly due to the reflections coming from the incident beam and the corresponding intensity is approximately $2 \times 10^{-3} \times V \mathrm{v}$ of argon under atmospheric pressure. Such a low value can be obtained by means of a carefully chosen set of diaphragms.

4. Measurement analysis. $-H \mathrm{~h}, V \mathrm{~h}, H \mathrm{v}$ and $V \mathrm{v}$ are measured at different temperatures and under different pressures. Then, $V \mathrm{~h}$ and $H \mathrm{v}$ are compared with $H \mathrm{~h}$, thus the evolution of $\beta$ and $\beta^{\prime}$ can be plotted.

By extrapolating the graphs $H \mathrm{~h}$ and $V \mathrm{v}$ at the origin, we deduce the contributions due to the parasitic light, which allows for the corrections of $\mathrm{Hh}$ and $V \mathrm{v}$ and the calculation of $\eta$. The original value $\eta_{\mathrm{o}}$ deduced from the graph of $\eta$ versus pressure $P$, for an isotropic gas, whithout Raman spectrum such as argon, is the depolarization ratio due to the finite aperture of diaphragms. This constant value must be deduced from all the values of $\eta(P)$ for all isotropic and anisotropic gases.

Even under moderate pressures, errors in the measurement of the depolarized components can be introduced by accidental depolarizations; but its effects can be limited, by using good window bearing. It's shown by graph 1: experiments (A) and (B)

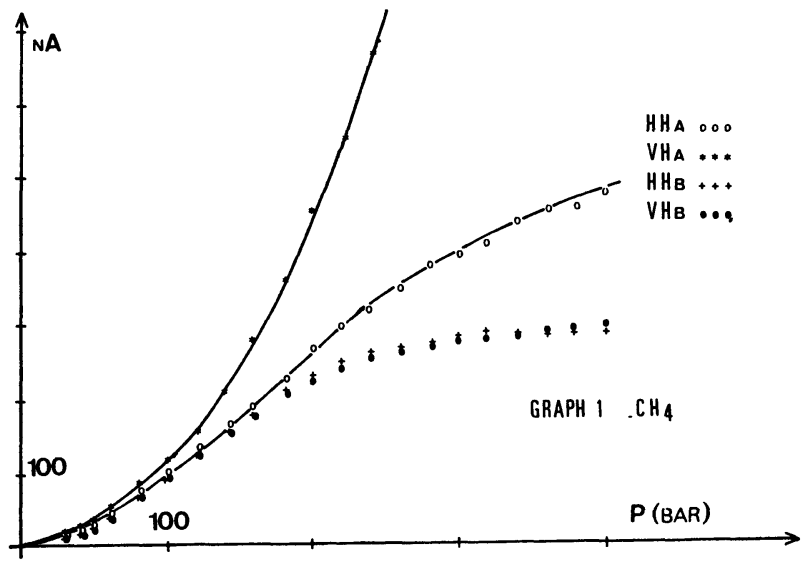

GrAPH 1. - Effect of the window bearing quality upon the depolarized intensities.

have been made in the same pressure range and temperature. In the second series of experiments (B) an improvement of the planeity of the polished bearing, considerably reduced the windows' depolarization, so that no correction was necessary to calculate $\eta$. It can be observed that in the (A) experiment the value of $V \mathrm{~h}$ is extremely high, as compared with the real $\mathrm{Vh}$ value practically observed in the (B) experiment. In (B), the values of $H \mathrm{~h}$ and $V \mathrm{~h}$ are similar. The graph 1 shows that the stress induced depolarization of window perturbes more $V \mathrm{~h}$ than $H \mathrm{~h}$; it's in agreement with (1).
The correction (2) permits practically to calculate $\eta$ even in experiment (A) up to a pressure of 200 bar. In experiment (B), $\eta$ is practically equal to $H \mathrm{~h} / V \mathrm{v}$, no correction is necessary. Nevertheless correction (2) can be very useful if quality of bearing is not exceptional.

The experiments, shown in graph 1 , have been made with methane which presents no depolarization under zero pressure, when the Raman spectrum is supressed by an interferential filter in front of the P.M. It can be noted that the extrapolated value under low pressure:

$\eta_{\mathrm{o}}=0.5 \times\left(10^{-3}\right)$ corresponds to that obtained with argon in a similar experiment: it's due to the finite diaphragms' aperture which is an apparatus characteristic. As previously said, we reported the values $\eta-\eta_{\mathrm{o}}$ on graph 2 and 3 .

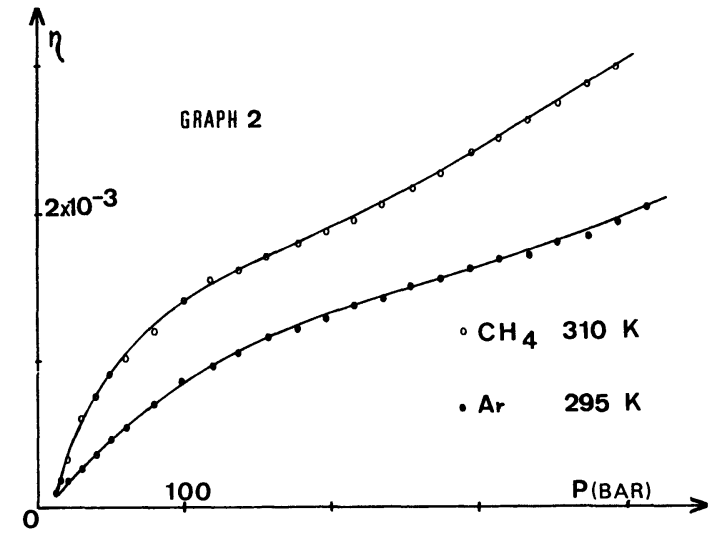

GrAPH 2. - Depolarization ratio versus pressure for isotropic gases.

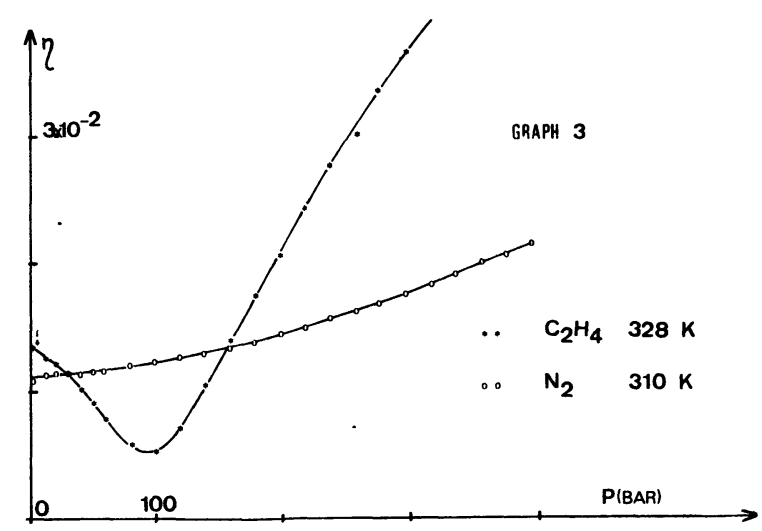

GrAPH 3. - Depolarization ratio pressure for anisotropic gases.

Our measurements have been made in a range of 0 to 400 bars with isotropic gases $\left(\mathrm{Ar}\right.$ and $\left.\mathrm{CH}_{4}\right)$ and anisotropic gases $\left(\mathrm{N}_{2}\right.$ and $\left.\mathrm{C}_{2} \mathrm{H}_{6}\right)$. Similar results have been commented (4) and (9). An collision induced anisotropy effect augmented with an aniso- 
tropic effect proper $I_{p}$ to all anisotropic molecules could thus be brought into evidence.

5. Conclusion. - We have described a mechanism permetting the reproducible study of depolarization of the light scattered by isotropic or anisotropic molecules.
Depolarization ratio up to 500 bar can be measured

a) by the minimization of stressed windows' birefringence and the corrections made to take it into account,

b) by limiting the inclination of the scattered rays,

c) by reducing the parasitic light by an adequate set of diaphragms.

\section{References}

[1] Buckingham A. D. and Dunmur D. A., Trans. Faraday Soc. 542 (1968) 1772.

[2] Alder B. J., Weis J. J. and Strauss H. L., Phys. Rev. A7 (1973) 281.

[3] Wright R. R. and Wang C. H., J. Chem. Phys. 61 (1974) 2707.

[4] Berrue J., Chave A., Dumon B. and Thibeau. M., J. Physique 37 (1976) 845.

[5] Berrue, J. (1975) Thèse $3^{\text {e }}$ cycle U.E.R. Sciences - Université Angers.

[6] Triki A., Oksengorn B. and Vodar B., C. R. Hebd. Séan. Acad. Sci. 36 Série B (1973) 413.
[7] Watson C. and Rowell L., J. Chem. Phys. 61 (1974) 2666.

[8] - Thibeau M., Oxsengorn B. and Vodar B., J. Physique 29 (1968) 287.

- Levine H. B. and Birnbaum G., Phys. Rev. Lett. 20 (1968) 439.

- Berrue J., Chave A., Dumon B. and Thibeau M.. J. Physique Lett. 37 (1976) L-165.

- BeRne B. J. and PeCORA R., Dynamic light scattering (Wiley Interscience, New York), 1976.

[9] Thibeau M., Thèse, Paris no 4302 (1970). 